\title{
ANALISIS VISUAL DAN ISI KARYA KALIGRAFI DEKORASI HASIL MTQ KHATTIL QURAN TINGKAT KABUPATEN BULELENG KE-26
}

\author{
Jajang S. ${ }^{1)}$; G. N. Widnyana ${ }^{2}$; dan E. Herliyani ${ }^{3)}$ \\ Prodi Desain Komunikasi Visual, Fakultas Bahasa dan Seni \\ Universitas Pendidikan Ganesha, Singaraja, Bali, Indonesia \\ Email: jajang.suryana@undiksha.ac.id'; nyoman.widnyana@undiksha.ac.id²; elly.herliany@undiksha.ac.id ${ }^{3}$
}

\begin{abstract}
This descriptive qualitative research is aimed at analyzing the calligraphy participating in Khattil Quran Competition in the 26th MTQ in Buleleng Regency. The works were visually analyzed using questioning approach which adapted Poster/visual analysis worksheet (Serianz, 2005) and The NARA Photo Analysis Sheet, which contained 7 simplified main questions, comprising question about: 1) dominant color, 2) use of symbols, 3) words that are presented visually; 4) the condition of the symbols (when they are needed); 5) message which are either explicitly stated or implied; 6) composition, dan 7) font variation. Content analysis was used to examine the style and composition of the calligraphy. The pattern of the calligraphy was analyzed by answering 6 questions that refer to letters variation, style of writing, accuracy of the contents (which was citation from the Quran), the rules of language use that are applicable for the work of calligraphy.

The results of the analysis indicate that most of the decorative calligraphy did not meet the criteria for a competition. Seven out of nine decorative calligraphy (each of which representing the nine districts in the region) did not show the basic requirement as a calligraphy work of art. There were a number of writing style which neither visually representative nor accurate. Mistakes are considered serious since the materials for creating the calligraphy were provided by the committee including the guidelines. Another mistake is the layout of the content (how to locate the verse, the choice of the font style, and the reading direction) which was considered as the second type mistake which was to do with experience with visual art management. This problem was to be followed up by the researcher team as a prospective area for community service program in the future.
\end{abstract}

Key words: khattil quran, MTQ, calligraphy, analysis, mistakes, layout

\begin{abstract}
ABSTRAK
Penelitian deskripstif kualitatif ini bertujuan untuk memeriksa karya kaligrafi hasil lomba Khattil Quran pada MTQ Ke-26 Tingkat Kabupaten Buleleng. Karya-karya dianalisis secara visual menggunakan pendekatan pertanyaan-pertanyaan yang diadaptasi dari pola Poster/Visual Analysis Worksheet Serianz (2005) dari The NARA Photo Analysis Sheet, yang disederhanakan menyangkut 7 pertanyaan utama yaitu: 1) warna dominan, 2) simbol yang digunakan, 3) kondisi simbol (jika digunakan), 4) katakata yang ditampilkan secara visual, 5) pesan yang tersurat dan tersirat, 6) komposisi, dan 7) keragaman penggunaan huruf. Analisis isi digunakan untuk memeriksa pola kaligrafi yang digunakan di dalam karya terdiri atas 6 pertanyaan terutama menyangkut kajian struktur huruf, pola penulisan, dan aturan kebenaran isi kalimat (ayat-ayat Al-Quran) yang ditulis sebagai karya kaligrafi.

Hasil analisis menunjukkan bahwa sebagian besar karya kaligrafi dekorasi, masih kurang memenuhi standar karya kaligrafi untuk lomba. Tujuh dari sembilan karya kaligrafi dekorasi, masingmasing mewakili sembilan kecamatan di Buleleng, masih menunjukkan banyak kesalahan tulis yang sangat mendasar. Kesalahan itu dianggap fatal karena bahan tulis kaligrafi telah disediakan oleh panitia sebagai pedoman penulisan karya. Kesalahan lainnya, terutama masalah layout isi tulisan (: penempatan potongan ayat, pemilihan jenis huruf, dan layout arah baca) dipandang sebagai bentuk kesalahan tingkat dua, karena lebih terkait dengan masalah pengalaman pengelolaan bidang kesenirupaan. Permasalahan terakhir akan menjadi bahan tindak lanjut bagi tim peneliti sebagai bahan yang bisa dipertimbangkan untuk kegiatan pembinaan dalam bentuk pengabdian.
\end{abstract}

Kata kunci: khattil quran, MTQ, kaligrafi, analisis, kesalahan, layout 


\section{PENDAHULUAN}

Karya kaligrafi masih belum banyak dibicarakan. Budaya kaligrafi masyarakat Indonesia berbeda dengan budaya kaligrafis Jepang, China, dan Korea. Masyarakat Indonesia belum memiliki budaya kaligrafi secara khusus, lebih khusus lagi yang terkait dengan jenis tulisan dan bahasa tertentu. Beberapa kegiatan yang tampak secara rutin dilakukan di antaranya dalam kegiatan Musabaqah Tilawatil Quran, yang salah satu rangkaian kegiatannya adalah berupa lomba Khattil Quran, lomba menulis kaligrafi ayat-ayat Al-Quran. Budaya ini telah menyuburkan kegiatankegiatan yang melengkapinya di lingkungan pesantren maupun mesjid-mesjid dan sekolahsekolah berbasis Islam. Sebuah fenomena menarik yang patut mendapat perhatian dari sisi kekayaan budaya bangsa sekaligus sebagai bahan dokumentasi pembelajaran.

Bidang bahasan kaligrafi menjadi salah satu bagian penting dalam kajian desain komunikasi visual. Sebuah karya kaligrafi adalah karya komunikasi yang secara langsung akan mengundang respons penikmat karya. Sebuah kaligrafi pada dasarnya berisi informasi yang dikomunikasikan oleh pembuatnya. Artinya, keterbacaan isi sebuah karya kaligrafi menjadi penting sebagai bentuk objek komunikasi. Isi kaligrafi, dalam konteks penelitian ini, adalah ayat-ayat Al-Quran, yang terkait dengan aturan-aturan penyusunan dan penulisan hurufnya. Karya kaligrafi terdiri atas dua hal, yang utama berupa tulisan dan yang melengkapinya berupa hiasan. Jika ada kaligrafi yang mengusung hiasan semata, maka ada sisi utama yang kurang mendapat perhatian: keterbacaan sebagai tujuan komunikasi. Sejumlah pelukis menggunakan kaligrafi sebagai bentuk wadah ekspresi, oleh karena itu keterbacaan isi kaligrafi kerap diabaikan, karena pelukis mengolah karya kaligrafi hanya untuk mengejar tuntutan estetis semata. Intinya, mereka menemukan kenikmatan berkaligrafi dengan mengembalikan olahan kaligrafi kepada unsur dasar huruf semata.

Pengembangan keterampilan merancang kaligrafi mushaf dan dekorasi tampaknya belum banyak mendapat penanganan secara profesional. Banyak kasus di lapangan, ketika "musim MTQ" tiba, cara bimbing serabutan mulai dilakukan. Seminggu atau bahkan kurang dari seminggu, para calon peserta lomba dalam kegiatan MTQ mulai memasuki program latihan. Semua itu dilakukan secara dadakan. Belum banyak program pelatihan yang tertib jadwal, apalagi dalam ruang khusus dan waktu khusus sebagai program latihan berkurikulum. Rata-rata masyarakat pegiat MTQ melakukan persiapan lomba tanpa perencanaan khusus. Hal itu dialami oleh peneliti ketika beberapa kali diminta menjadi pembimbing para calon peserta lomba. Dan, LPTQ (Lembaga Pembinaan Tilawatil Quran), khususnya di Kabupaten Buleleng, masih berada pada posisi aktif berkegiatan hanya pada saat menjelang lomba. Alasan klasik "kekurangan dana kegiatan" adalah hal klise yang kerap menjadi tameng tunggal yang seakan tak bisa ditembus. Banyak peserta lomba yang memiliki prestasi khusus, berangkat dari hasil pembinaan di lingkungan keluarga. Bisa dibayangkan jika ada lembaga khusus pembinaan calon lombawan yang resmi dan tertib jadwal serta ditangani oleh para pakar di bidang kegiatan masing-masing. Bagaimana kondisi karya hasil lomba MTQ Khattil Quran, dengan gambaran pola pembinaan seperti telah disebutkan, menarik untuk diperiksa dan dianalisis.

Penelitian tentang karya kaligrafi menjadi sangat menarik dan penting karena kajian bidang ini masih jarang dilakukan. Terutama, tentang kaligrafi hasil lomba dalam MTQ Khattil Quran. Kegiatan lomba tahunan ini berlangsung dari tingkat kecamatan, kabupaten, provinsi, hingga nasional. Bahkan, kegiatan MTQ tingkat internasional pun melibatkan kegiatan lomba khattil quran dimaksud. Khat atau kaligrafi karya peserta MTQ menjadi menarik karena dibuat kebanyakan bukan oleh masyarakat seni rupa atau desain. Mereka adalah sebagai pelaku kegiatan yang mengandalkan sisi pengalaman semata dalam kegiatan memroduksi kaligrafi. Sementara itu, hanya sedikit saja yang berangkat dari lembaga yang secara resmi membina kegiatan berbasis kurikulum resmi. Kondisi tadi me- 
mungkinkan hadirnya karya-karya yang menunjukkan kekurangan dari sisi teori seni, atau sebaliknya banyak menampilkan hal-hal baru yang selama ini kurang mendapat perhatian dan bahasan dalam teori seni rupa resmi. Sisi kepentingan masalah tersebut adalah persoalan utama yang menjadi perhatian dalam penelitian ini.

Penelitian deskriptif kualitatif ini adalah untuk memeriksa karya-karya kaligrafi yang dibuat oleh peserta MTQ Khattil Quran tingkat Kabupaten Buleleng ke-26. Karya-karya yang diperiksa terdiri atas karya Bidang Dekorasi dan Bidang Mushaf. Kedua jenis karya tersebut lebih banyak melibatkan kegiatan bidang desain dan kesenirupaan. Sementara itu satu bidang lomba lainnya, Bidang Naskah, cenderung berupa kegiatan pembuatan kaligrafi murni. Oleh karena itu, dalam penelitian ini hanya menyoroti hasil kegiatan lomba dua bidang yang telah disebut terdahulu. Satu bidang lomba kaligrafi lainnya, lomba kaligrafi kontemporer, belum dilaksanakan dalam MTQ Khattil Quran tingkat Kabupaten Buleleng ke-26 ini.

Karya-karya kaligrafi hasil lomba dianalisis secara visual menggunakan pendekatan pertanyaan-pertanyaan yang diadaptasi dari pola Poster/Visual Analysis Worksheet yang dikembangkan oleh Serianz (2005) dari The NARA Photo Analysis Sheet (10 pertanyaan berbasis analisis tampilan visual). Pertanyaan-pertanyaan pada penelitian ini lebih disederhanakan menyangkut 7 pertanyaan utama yaitu: 1) warna dominan, 2) simbol yang digunakan, 3) kondisi simbol (jika digunakan), 4) kata-kata yang ditampilkan secara visual, 5) pesan yang tersurat dan tersirat, 6) komposisi, dan 7) keragaman penggunaan huruf. Analisis isi digunakan untuk memeriksa pola kaligrafi yang digunakan di dalam karya terdiri atas 6 pertanyaan terutama menyangkut kajian struktur huruf, pola penulisan, dan aturan kebenaran isi kalimat (ayat-ayat Al-Quran) yang ditulis sebagai karya kaligrafi.

\section{Musabaqah Tilawatil Quran}

Musabaqah Tilawatil Quran (MTQ) adalah kegiatan perlombaan yang terkait den- gan bidang-bidang kajian Quran. Membaca (tilawah dan tartil), menghafal (tahfizh), mengupas (fahmil dan syarhil), menulis (khat: naskah, mushaf, dan dekorasi), karya ilmiah, dan masih banyak lagi bentuk kegiatan semua terkait kajian Al-Quran. Kegiatan ini, seperti dicatat dalam http://id.wikipedia.org (diakses Senin, 21 Maret 2016, 19:54):

"MTQ telah ada di Indonesia sejak tahun 1940-an sejak berdirinya Jami'iyyatul Qurro wal Huffadz yang didirikan oleh Nahdlatul Ulama, ormas terbesar di Indonesia.

Sejak tahun 1968, saat Menteri Agama dijabat K.H. Muhammad Dahlan (salah seorang ketua Pengurus Besar Nahdlatul Ulama) MTQ dilembagakan secara nasional. MTQ pertama diselenggarakan di Makassar pada bulan Ramadhan tahun 1968. Kala itu hanya melembagakan tilawah dewasa saja dan melahirkan Qari Ahmad Syahid dari Jawa Barat dan Muhammadong dari Sulawesi Selatan. MTQ kedua diselenggarakan di Banjarmasin tahun 1969. Tahun 1970 MTQ ketiga diselenggarakan di Jakarta dengan acara yang sangat meriah".

Menurut sejumlah catatan, MTQ diselenggarakan dalam lingkungan yang beragam. MTQ untuk umum (anak-anak hingga dewasa) diselenggarakan secara bertahap mulai dari tingkat kecamatan, kabupaten, provinsi, dan puncaknya tingkat nasional. Di lingkungan perguruan tinggi pun dilaksanakan secara nasional. Di samping MTQ dikenal juga bentuk penyelenggaraan lain yang kegiatannya berupa seleksi awal untuk tingkat lanjutan yang disebut STQ (Seleksi Tilawatil Quran).

Lomba yang diselenggarakan dalam MTQ, pada periode tertentu, mengusung penambahan atau peningkatan jenisnya. Tetapi, lomba utama dalam MTQ seperti telah disebutkan adalah membaca (tilawah dan tartil), menghafal (tahfizh), dan mengupas (fahmil dan syarhil) isi Al-Quran. Jenis lomba lainnya seperti khat dan lebih khusus puitisasi terjemahan Al-Quran, menjadi bagian tambahan di samping lomba utama. Lomba tilawah dan tartil dibagi dalam kelompok jenis kelamin, selanjutnya dikelompokkan lagi berdasarkan tingkat usia: anak-anak, remaja, dewasa, dan cacat netra. 
Cabang lomba lainnya adalah tahfizh. Lomba tahfizh terdiri atas hafalan 1 juz, 5 juz, 10 juz, 20 juz, dan 30 juz. Masing-masing tingkat hafalan ini dibedakan lagi berdasarkan jenis kelamin dan tingkat usia, sama seperti pada lomba tilawah dan tartil. Oleh karena itu, jenis lomba utama ini menjadi sangat banyak anak cabangnya.

Lomba yang terkait dengan pemahaman, yang terdiri atas fahmil dan syarhil, pada dasarnya adalah lomba kelompok. Lomba fahmil mengutamakan pemahaman isi ayat atau inti surat. Bentuk pelaksanaan lombanya dikemas dalam pola kegiatan cerdas-cermat. Kekompakan kelompok menjadi penting dalam jenis lomba ini. Berbeda dengan jenis lomba syarhil yang lebih mengutamakan pemahaman lebih mendalam yaitu tafsir atas isi ayat atau inti surat. Kemasan lomba ini hampir sama dengan presentasi karya ilmiah, bisa juga dalam bentuk kemasan ceramah atau pidato yang dilengkapi dengan tampilan lain dalam bentuk syarahan dan tilawah. Oleh karena itu, lomba syarhil sama seperti fahmil, dilaksanakan secara berkelompok. (http:// tilawah-lpu.blogspot.co.id/2015/06/cabanglomba-dalam-mtq.html, diakses Selasa, 22 Maret 2016, 09:33).

\section{Musabaqah Khattil Quran}

Bidang-bidang kegiatan lomba dalam MTQ, seperti telah disinggung, ada yang terkait dengan kegiatan menulis (khat) ayatayat Al-Quran. Kegiatan ini terdiri atas tiga bidang kegiatan yang berbeda secara mendasar. Kegiatan lomba pertama berupa menulis ayatayat Al-Quran sesuai pola keperluan naskah cetak Al-Quran. Secara pakem, naskah AlQuran mengikuti rasm Utsmani (bentuk dan model huruf resmi Al-Quran cetak). Pola rasm Utsmani itulah yang menjadi pedoman kegiatan lomba kaligrafi jenis yang pertama ini. Semua kaligrafi ditata dengan menggunakan pola susun jenis huruf naskhi. Huruf naskhi, seperti asal namanya, adalah huruf khas naskah AlQuran. Jenis huruf ini adalah huruf standar yang sangat jernih, mudah dibaca, serta ditulis lengkap dengan syakalnya.

Lomba kaligrafi naskhi (kaligrafi naskah) mengutamakan penulisan keaslian huruf naskhi, 'tidak mengutamakan hiasan', dan pola susun tulisannya seperti yang terdapat dalam halaman Al-Quran. Penilaian karya kaligrafi jenis ini mengutamakan penilaian kebenaran isi tulisan, struktur huruf, penempatan spasi antarhuruf, dan komposisi naskah secara keseluruhan. Estetika karya kaligrafi naskhi, lebih dominan dalam tampilan keindahan standar tulisan. Improvisasi tampilan tulisan hanya pada bagian-bagian tertentu yang tidak mengganggu struktur bentuk asli hurufnya.
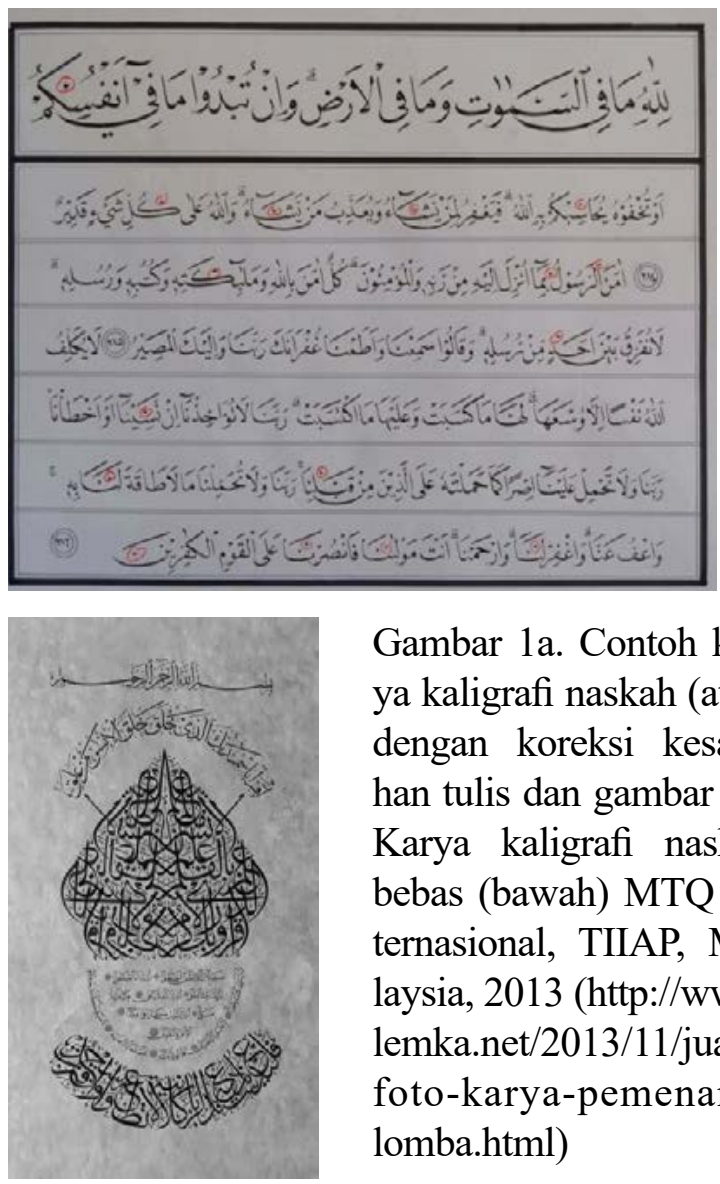

Gambar 1a. Contoh karya kaligrafi naskah (atas) dengan koreksi kesalahan tulis dan gambar $1 b$. Karya kaligrafi naskah bebas (bawah) MTQ Internasional, TIIAP, Malaysia, 2013 (http://www. lemka.net/2013/11/juarafoto-karya-pemenanglomba.html)

Lomba kaligrafi naskah, pada pelaksanaannya, terdiri atas dua paket kegiatan. Paket kegiatan pertama berupa lomba menulis naskah (satu halaman) dengan mengutamakan rasm standar. Sebagaimana sebuah halaman naskah dalam halaman Al-Quran, naskah yang harus diselesaikan dalam jenis lomba ini adalah naskah, lazimnya, satu surat pendek utuh, atau beberapa ayat panjang dari bagian surat tertentu (Gambar 1, atas). Kegiatan kedua adalah menulis naskah lengkap tetapi dengan pola tulis di luar pola huruf naskhi (Gambar 
1b bawah). Entah dengan pertimbangan apa, para perancang kegiatan ini memasukkan paket kegiatan jenis kedua dalam lomba kaligrafi naskah. Hal itu agak sulit ditelusuri secara konsep, karena lomba khattil quran jenis kedua itu berawal dari kegiatan lomba MTQ tingkat internasional.

Lomba kaligrafi paket kedua adalah kaligrafi mushaf. Jenis kaligrafi ini selain diikat dengan gaya tulis naskhi, juga dilengkapi unsur-unsur tambahan berupa hiasan pinggir (iluminasi) sebagaimana tampilan sebuah halaman awal atau tengah Al-Quran. Penilaian karya kaligrafi hasil lomba bidang ini lebih beragam karena terkait dengan penilaian standar penulisan huruf ditambah penilaian tentang keindahan halaman sebuah mushaf. Pola mushaf pada dasarnya tidak banyak ragamnya. Biasanya ada bagian hiasan kepala halaman, bingkai, hiasan pinggir, dan hiasan bawah. Sementara itu, bagian tulisan harus ditata resmi sebagaimana susunan tulisan dalam sebuah halaman Al-Quran.

Cabang lomba kaligrafi ketiga adalah kaligrafi hiasan, terdiri atas dua format karya: dekorasi dan kontemporer. Pada cabang lomba ini jenis huruf yang biasa digunakan sebagai media estetis diperkenankan hingga 7 jenis huruf. Pada sebuah karya kaligrafi dekorasi bisa ditemukan empat hingga tujuh jenis huruf yang berbeda sebagai pola huruf yang digunakan dalam menampilkan suatu rangkaian ayat tertentu. Oleh karena itu, arah baca tulisan dalam karya kaligrafi dekorasi menjadi tantangan yang sering menyebabkan kaligrafer keliru dalam menempatkan bagian-bagian isi tulisan. Khusus untuk kaligrafi kontemporer, tuntutan utama isi karya sejalan dengan karya estetis lukisan pada umumnya. Ikatannya lebih longgar, di luar kebenaran penulisan struktur huruf beserta cara susunnya yang tetap memperhitungkan masalah kebenaran dan keterbacaan isinya.

Selain tulisan yang beragam, dalam kaligrafi dekorasi akan ditemukan jumlah hiasan yang dominan sebagai isi tampilan karya. Hiasan yang dipasang dalam kaligrafi dekorasi berbeda dengan kaligrafi mushaf. Mushaf dibatasi oleh tampilan halaman yang harus menggambarkan sebuah halaman atau dua halaman awal Al-Quran. Jika pada kaligrafi mushaf hiasan dijadikan sebagai bingkai, maka pada kaligrafi dekorasi, hiasan bisa difungsikan dan diposisikan lebih bebas. Bahkan pada kenyataannya, hiasan harus menggambarkan inti isi ayat yang ditampilkan. Tetapi di lapangan, kecenderungan yang muncul adalah pola tampilan hiasan yang hampir sama antara kaligrafi mushaf dengan dekorasi. Yang membedakan keduanya adalah jenis huruf yang digunakan.

\section{Kaligrafi}

Kaligrafi adalah seni (me)tulis(an) indah. Dalam istilah bahasa Arab, kegiatannya dikenal dengan sebutan husnul khat, keindahan tulisan. Dalam lingkup MTQ sebutan istilahnya menjadi khattil quran, penulisan (ayatayat) Al-Quran. Kaligrafi berciri Islam, sejalan dengan perkembangan pemahaman dan kebutuhan syiar agama Islam sebagai pendukung utama keberadaannya telah dihidupkan jauh pada masa-masa awal abad Islam di Timur Tengah.

Dalam http://septiyenabdullah.blogspot.com/2013/ disebutkan bahwa: Pembentukan huruf abjad Arab sehingga menjadi dikenal pada masa-masa awal Islam memakan waktu berabad-abad. Inskripsi Arab Utara bertarikh $250 \mathrm{M}, 328 \mathrm{M}$ dan $512 \mathrm{M}$ menunjukkan kenyataan tersebut. Dari inskripsi-inskripsi yang ada, dapat ditelusuri bahwa huruf Arab berasal dari huruf Nabati yaitu huruf orangorang Arab Utara yang masih dalam rumpun Smith yang terutama hanya menampilkan huruf-huruf mati. Dari masyarakat Arab Utara yang mendiami Hirah dan Anbar tulisan tersebut berkembang pemakaiannya ke wilayahwilayah selatan Jazirah Arab.

Beberapa ragam kaligrafi awalnya dinamakan berdasarkan asal kota tempat dikembangkannya tulisan. Dari berbagai karakter tulisan hanya ada tiga gaya utama yang berhubungan dengan tulisan yang dikenal di Makkah dan Madinah yaitu Mudawwar (bundar), Mutsallats (segitiga), dan Ti'im (kembar yang tersusun dari segitiga dan bundar). Dari tiga inipun hanya dua yang diutamakan yaitu gaya 
kursif dan mudah ditulis yang disebut gaya Muqawwar berciri lembut, lentur dan gaya Mabsut berciri kaku dan terdiri atas goresangoresan tebal (rectilinear). Dua gaya inipun menyebabkan timbulnya pembentukan sejumlah gaya lain lagi di antaranya Mail (miring), Masyq (membesar) dan Naskh (inskriptif).

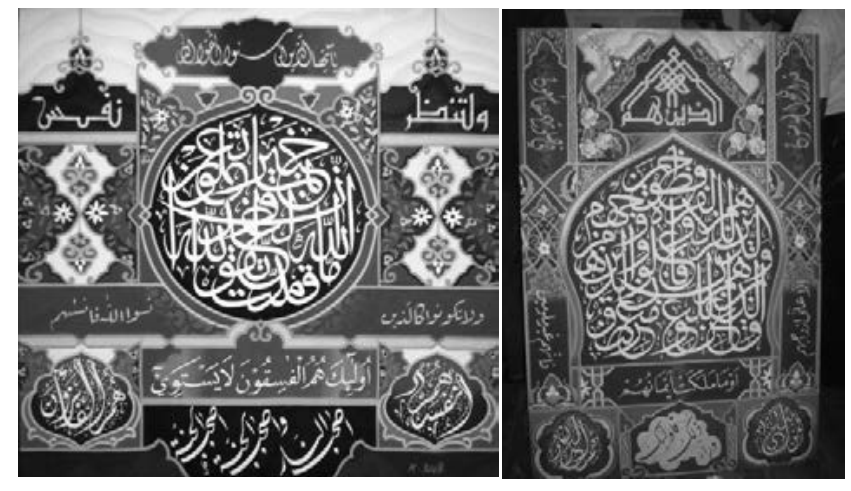

gunakan juga sebagai pedoman dalam penilaian lomba-lomba kaligrafi masa kini. Enam standar kaligrafi ini pada dasarnya terkait dengan model huruf yang digunakan. Tetapi, semua model huruf pada dasarnya telah memiliki kekhususan dalam penggunaan tertentu. Oleh karena itu, beberapa standar huruf hanya bisa digunakan dalam penulisan-penulisan yang lebih bersifat bebas, sementara huruf lainnya tetap menjadi standar wajib dalam penulisan ayat-ayat Al-Quran yang resmi.

$$
\text { Lebih lengkap dikemukakan }
$$
dalam http://septiyenabdullah.blogspot. com/2013/, "Gaya dan teknik menulis kaligrafi semakin berkembang terlebih pada periode ini semakin banyak kaligrafer yang lahir, di antaranya Ad-Dahhak ibn 'Ajlan yang hidup pada masa Khalifah Abu AbGambar 2. Contoh karya kaligrafi dekorasi (kiri) MTQ Nasional, Bengkulu 2010 (http://kaligrafi-man-baureno.blogspot. co.id/2012/02/karya-finalis-mtq-nasionalbengkulu.html\#links) dan karya kaligrafi dekorasi (kanan) MTQ Nasional, Ambon 2012 (http://ahmadfauzanalamsyah.blogspot. co.id/2014/01/hasil-karya-para-khatat-di-mtqnasional.html)

"Gaya Masyq dan Naskh terus berkembang, sedangkan Mail lambat laun ditinggalkan karena kalah oleh perkembangan Kufi. Perkembangan Kufi pun melahirkan beberapa variasi baik pada garis vertikal maupun horizontalnya, baik menyangkut huruf-huruf maupun hiasan ornamennya. Muncullah gaya Kufi Murabba' (lurus-lurus), Muwarraq (berdekorasi daun), Mudhaffar (dianyam), Muwaraq (berdekorasi daun), Mutarabith Mu'aqqad (terlilit berkaitan), dan lainnya. Demikian pula gaya kursif mengalami perkembangan luar biasa bahkan mengalahkan gaya Kufi, baik dalam hal keragaman gaya baru maupun penggunannya, dalam hal ini penyalinan alQur'an, kitab-kitab agama, surat-menyurat dan lainnya".

Dalam perkembangan selanjutnya, dikenal al-aqlam al-sittah yaitu standar penulisan kaligrafi yang kemudian banyak di- bas As-Shaffah (750-754 M), dan Ishaq ibn Muhammad pada masa Khalifah al-Manshur (754-775 M) dan al-Mahdi (775-786 M). Ishaq memberi kontribusi yang besar bagi pengembangan tulisan Tsuluts dan Tsulutsain dan mempopulerkan pemakaiannya. Kemudian kaligrafer lain yaitu Abu Yusuf as-Sijzi yang belajar Jalil kepada Ishaq. Yusuf berhasil mengembangkan huruf yang lebih halus dari sebelumnya.

Adapun kaligrafer periode Bani Abbasiyah yang tercatat sebagai nama besar adalah Ibnu Muqlah yang pada masa mudanya belajar kaligrafi kepada Al-Ahwal al-Muharrir. Ibnu Muqlah berjasa besar bagi pengembangan tulisan kursif karena penemuannya yang spektakuler tentang rumus-rumus geometrikal pada kaligrafi yang terdiri dari tiga unsur kesatuan baku dalam pembuatan huruf yang ia tawarkan yaitu : titik, huruf alif, dan lingkaran. Menurutnya setiap huruf harus dibuat berdasarkan ketentuan ini dan disebut al-Khat al-Mansub (tulisan yang berstandar). Ia juga mempelopori pemakaian enam macam tulisan pokok (al-Aqlam as-Sittah) yaitu Tsuluts, Naskhi, Muhaqqaq, Raihani, Riqa', dan Tauqi' yang merupakan tulisan kursif. Tulisan Naskhi dan Tsuluts menjadi populer dipakai karena usaha Ibnu Muqlah yang akhirnya bisa menggeser dominasi khat Kufi".

Pengembangan terus berlanjut hingga 
didapatkan standar baru yang menyempurnakan standar lama. Salah satu jenis huruf yang kemudian menjadi standar lainnya adalah jenis huruf Diwani. Kelompok huruf Diwaniini pada dasarnya adalah pengembangan dari model huruf yang telah ada sebelumnya yaitu jenis huruf Ta'liq dan Nasta'liq. Lebih lengkap keterangannya bisa diperiksa dalam lanjutan catatan http://septiyenabdullah.blogspot. com/2013/ sebagai berikut:

"Dalam perkembangan selanjutnya, wilayah Arab diperintah oleh Dinasti Utsmaniyah (Ottoman) di Turki. Perkembangan kaligrafi sejak masa dinasti ini hingga perkembangan terakhirnya selalu terkait dengan dinasti Utsmaniyah Turki. Perkembangan kaligrafi pada masa Utsmaniyah ini memperlihatkan gairah yang luar biasa. Kecintaan kaligrafi tidak hanya pada kalangan terpelajar dan seniman tetapi juga beberapa sultan bahkan dikenal juga sebagai kaligrafer. Mereka tidak segan-segan untuk merekrut ahli-ahli dari negeri musuh seperti Persia, maka gaya Farisi pun dikembangkan oleh dinasti ini. Adapun kaligrafer yang dipandang sebagai kaligrafer besar pada masa dinasti ini adalah Syaikh Hamdullah al-Amasi yang melahirkan beberapa murid, salah satunya adalah Hafidz Usman. Perkembangan kaligrafi Turki sejak awal pemerintahan Utsmaniyah melahirkan sejumlah gaya baru yang luar biasa indahnya, berpatokan dengan gaya kaligrafi yang dikembangkan di Baghdad jauh sebelumnya. Yang paling penting adalah Syikastah, Syikastah-amiz, Diwani, dan Diwani Jali. Syikastah (bentuk patah) adalah gaya yang dikembangkan dari Ta'liq dan Nasta'liq awal. Gaya ini biasanya dipakai untuk keperluan-keperluan praktis. Gaya Diwani pun pada mulanya adalah penggayaan dari Ta'liq. Tulisan ini dikembangkan pada akhir abad ke-15 oleh Ibrahim Munif, yang kemudian disempurnakan oleh Syaikh Hamdullah. Gaya ini benar-benar kursif, dengan garis yang dominan melengkung dan bersusun-susun. Diwani kemudian dikembangkan lagi dan melahirkan gaya baru yang lebih monumental disebut Diwani Jali, yang juga dikenal sebagai Humayuni (kerajaan). Gaya ini sepenuhnya dikembangkan oleh Hafidz Usman dan para muridnya".

\section{Estetika dan Keterbacaan Kaligrafi}

Keindahan kaligrafi sejak awal adalah keterbacaannya. Jika kaligrafi telah kehilangan unsur keterbacaannya, huruf-huruf yang ada dalam karya kaligrafi hanya sekadar media ekspresi semata. Makna yang ingin disampaikan menjadi kabur karena sebagian besar media komunikasi yaitu bagian kaligrafi yang visual telah dilebur dalam upaya memperindah bentuk. Di dalam kaligrafi unsur keindahan dan keterbacaan tetap menjadi penting sebagai dua bagian yang saling melengkapi.

Ali Akbar (1995, 22-24) menguraikan tentang makna keindahan kaligrafi seperti ditulis oleh At-Tauhidi, seorang penulis besar yang hidup pada masa pemerintahan Abbasiyyah. Ada tiga pokok keindahan yang berpadu dengan makna dalan karya kaligrafi seperti uraian berikut.

"Pertama, kaligrafi dianggap sebagai refleksi kebijaksanaan dan kualitas kesempurnaan manusia. Gaya dalam kaligrafi merupakan citra intelek yang mewujud dalam bentuk. Ini dicatat At-Tauhidi dalam beberapa pernyataan yang disebutkan dalam risalah ini. Misalnya disebutkan: Abbas berkata: Tulisan tangan adalah lidahnya tangan. Gaya adalah lidahnya intelek. Intelek adalah lidah bagi bagusnya kualitas dan tindakan. Dan bagusnya kualitas dan tindakan adalah kesempurnaan manusia.

Atau misalnya lagi dikatakan:

Kalam adalah kebijaksanaan yang utama. Tulisan tangan adalah keutamaan kalam. Gagasan adalah karunia yang kaya dari intelek, dan eloknya gaya adalah hiasan bagi seluruhnya itu.

Kedua, kaligrafi juga dianggap sebagai mutiara intelek, yang juga disebut beberapa kali, seperti yang disebutkan oleh Hisyam bin Al-Ahkam: "Tulisan tangan adalah perhiasan yang ditampakkan oleh tangan, dari emas murni intelek. Ia juga adalah kain sutera yang ditenun oleh kalam dengan benang kepiawaian". 
Sementara itu Bisyr al-Mu'tamir berkata: "Batin adalah tambang, intelek adalah mineral yang mulia, lidah adalah pekerja tambang, kalam adalah tukang emas, dan tulisan tngan adalah benda perhiasan yang telah jadi”.

Ketiga, kaligrafi, di lain pihak, merupakan perpaduan antara pikiran dan perasaan, kualitas intelek dan intuisi. Abu Dulaf A-'Ijli misalnya pernah berkata: "Kalam adalah tukang emas perkataan. Ia mencairkan dan mengungkapkan is hati, dan menampakkan batang-batang bagian tubuh di mana pikiran dan perasaan bermuara".

An-Namari suatu saat berkata: "Kalam adalah hewan-hewan beban bagi akal, kurir bagi fakultas-fakultas alamiah dan bagian tubuh yang utama dimana pikiran dan perasaan bermuara".

Nilai-nilai lain yang disebutkan adalah bahwa kaligrafi sebagai geometri spiritual, penggambaran jiwa, cinta, rasa, dan penampakan karakter seseorang. Di samping itu, kaligrafi juga dikaitkan dengan maslah duniawi, terutama ketika kaligrafi digunakan juga untuk mengungkapkan puisi-puisi cinta, bahkan ghazal, puisi tentang cinta yang tak terbalas".

Secara umum, kaligrafi berbahasa dan berhuruf Arab, pada umumnya digunakan untuk mengekspresikan nilai-nilai keagamaan. Karya jenis ini, sebagai bentuk media komunikasi, lebih mementingkan tampilan visual dan ungkapan makna yang disampaikan dengan lebih mempertimbangkan sisi keterbacaan isinya. Hiasan dan tulisan saling melengkapi ungkapan kesyukuran, kesukacitaan, kehambaan, kekaguman, kengerian, dan banyak hal yang melatari nilai-nilai yang ingin dikomunikasikan.

Dalam menambahkan hiasan, tak ada ketetapan yang harus dipatuhi, kecuali bentuk-bentuk yang terlarang. Oleh karena itu, akan didapatkan banyak varian hiasan pada kaligrafi, sesuai dengan di mana kaligrafi itu digubah. Kondisi lingkungan kerap memberi warna tambahan sebagai penanda kawasan. Tetapi, ada sesuatu yang menjadi paedoman, terutama ketika sumber asli menjadi pertimbangan khusus. Sejumlah ornamen geometris khas arabica kerap menjadi hiasan yang domi- nan. Warna-warna cerah biru-hijau-ungu di antara warna-warna dominan yang memenuhi karya kaligrafi dari kawasan Timur Tengah.

Satu contoh keterangan tentang pengembangan karya kaligrafi (khusus kaligrafi naskah) yang ada di lingkungan Nusantara, seperti dikemukakan dalam http://mushafnusantara. blogspot.com.

"Mushaf Al-Qur'an disalin sesuai dengan ruang dan waktu mushaf itu dibuat. Atau dengan kata lain, sesuai dengan latar budaya dan kondisi zamannya. Lokalitas budaya tempat mushaf disalin merupakan faktor yang ikut menentukan dan mempengaruhi variasi bentuk, motif dan warna iluminasi - demikian pula gaya kaligrafinya, dalam taraf tertentu.

Unsur kreativitas lokal, sebagai hasil serapan budaya setempat, terlihat dalam corak iluminasi yang sangat beragam, dan masingmasing daerah memiliki ciri khas sendiri. Iluminasi biasanya dicirikan dengan (1) pola dasar, (2) motif hiasan, dan (3) warna. Iluminasi tersebut lazimnya menghias tiga bagian Al-Qur'an, yaitu di awal, tengah, dan akhir $\mathrm{Al}$ Qur'an. Dalam hal kaligrafi, keunikan mushaf Nusantara di antaranya tampak dalam karakter "kaligrafi berhias" atau "kaligrafi floral", yaitu komposisi kaligrafi yang bermotif tetumbuhan. Kreativitas tulisan tersebut dituangkan khususnya pada kepala-kepala surah. Unsur kreativitas lokal itu, baik dalam iluminasi maupun kaligrafi, berkembang sangat leluasa dan berkarakter khas, bahkan dalam bentuk makhluk zoomorphic seperti Macan Ali di Cirebon".

Di Indonesia, pengembangan penulisan naskah mushaf maupun kaligrafi hiasan terus dilakukan. Banyak kegiatan yang menandai lahirnya mushaf Quran yang baru sesuai dengan peristiwa atau kondisi lembaga pendukung kegiatan tertentu. Yang paling akhir, seperti diuraikan dalam http://mushafnusantara. blogspot.com, kegiatan dan peristiwa itu terkait juga orang-orang terkenal yang mendukung kegiatan. Hal itu bisa saja terjadi, karena sebuah naskah mushaf Quran pada dasarnya selalu harus melalui pemeriksaan lembaga tertentu yang ditunjuk secara resmi oleh negara. Artinya, naskah mushaf 
atas nama siapapun atau lembaga manapun, selama isinya tetap terpelihara keasliannya, sah saja sebagai naskah mushaf Quran yang bisa digunakan.

"Setelah hampir satu abad terhenti, sejak akhir abad ke-19 atau awal abad ke-20, era baru dalam kreativitas seni mushaf tumbuh kembali sejak pembuatan Mushaf Istiqlal pada tahun 1991, yang diprakarsai oleh beberapa ahli dari ITB Bandung, seperti Mahmud Buchari, Prof. AD Pirous, Ir. Ahmad Noe'man, dan beberapa sarjana serupa lainnya. Pembuatan Mushaf Istiqlal itu berbarengan dengan penyelenggaraan Festival Istiqlal tahun 1991 dan 1995 di Jakarta. Mulai saat itu, gairah dalam pembuatan mushaf indah tampak tumbuh kembali, dan sampai saat ini telah ada beberapa mushaf, dalam bentuk naskah asli dan cetakan, yaitu Mushaf Sundawi (prakarsa Pemda Jawa Barat, 1997), Mushaf at-Tin (prakarsa keluarga mantan Presiden Soeharto untuk mengenang Ibu Tien, 2000), Mushaf Jakarta (prakarsa Pemda DKI Jakarta, 2002), dan Mushaf Kalimantan Barat (prakarsa Pemda Kalbar, 2003).

Berbeda dengan seni mushaf pada zaman dahulu yang keseluruhannya dibuat secara manual, "mushaf-mushaf kontemporer" ini dibuat dengan memanfaatkan teknologi komputer. Namun, keduanya sama-sama indah, mencerminkan kekayaan khazanah budaya bangsa Indonesia".

\section{METODE PENELITIAN}

Penelitian ini penelitian deskripstif kualitatif. Penelitian ini bertujuan memeriksa karya kaligrafi hasil lomba Khattil Quran pada $M T Q$ Ke-26 Tingkat Kabupaten Buleleng. Karya hasil lomba Khattil Quran berupa karya kaligrafi dekorasi dianalisis secara visual menggunakan pendekatan pola pertanyaan hasil adaptasi dari Poster/Visual Analysis Worksheet Serianz (2005) dari The NARA Photo Analysis Sheet. Pertanyaan-pertanyaan penelitian disederhanakan menyangkut 7 pertanyaan utama yaitu: 1) warna dominan, 2) simbol yang digunakan, 3) kondisi simbol (jika digunakan), 4) kata-kata yang ditampil- kan secara visual, 5) pesan yang tersurat dan tersirat, 6) komposisi, dan 7) keragaman penggunaan huruf. Bagian isi kaligrafi dianalisis menggunakan pola analisis isi yang menyangkut pemeriksaan pola susun kaligrafi yang digunakan di dalam karya. Analisis menyangkut 6 pertanyaan, terutama bertalian dengan kajian struktur huruf, pola penulisan, dan aturan kebenaran isi kalimat (ayat-ayat Al-Qur'an) yang ditulis sebagai karya kaligrafi.

\section{HASIL PENELITIAN}

Delapan karya kaligrafi dekorasi yang berhasil dikumpulkan mewakili peserta delapan dari sembilan kecamatan yang ada di Buleleng. Warna Dominan Karya Kaligrafi Dekorasi yang tampak dalam delapan karya kaligrafi dekorasi ini adalah warna biru. Warna biru yang digunakan beragam dari warna biru tua hingga biru muda. Tampaknya, biru menjadi warna "kesukaan" bagi para peserta lomba. Belum bisa ditafsir bahwa warna biru menjadi satu jenis warna yang dianggap mewakili tampilan kaligrafi keislaman. Di samping warna dasar biru, ada warna cokelat dan hijau dengan gradasinya, yang menjadi warna tampilan dalam karya-karya kaligrafi dekorasi yang dibuat oleh peserta lomba. Warna merah muda dan kuning menjadi warna yang melengkapi tampilan empat karya. Warna-warna tadi ditempatkan sebagai warna latar belakang dan warna aksen untuk bagian tampilan tertentu. Warna putih menjadi warna dominan (7 karya) dalam menampilkan bagian tulisan utama. Latar warna bagian tulisan yang gelap, bisa biru tua, cokelat atau pun hijau tua, menjadi lahan yang nyaman untuk warna putih sebagai warna tumpangannya. Ketika digunakan warna lain sebagai warna tulisan, warna-warna tersebut kurang menampakkan kontras yang bagus. Simbol yang Digunakan dalam Karya Kaligrafi Dekorasi hanya tampak pada satu karya, Simbol tersebut adalah simbol yang kerap muncul dalam tampilan benda kaligrafi Islami, yaitu tulisan nama Allah dan Muhammad. Simbol ini kerap muncul sebagai "keharusan" yang ditampilkan di tempat khusus (lebih khusus suci), atau tempat utama dan 
penting di suatu ruangan. Kedua tulisan tadi lebih banyak ditemukan menjadi bagian tampilan hiasan mihrab mesjid. Tulisan nama Allah ditempatkan di sebelah kanan (bagi pelihat), sementara tulisan Muhammad di sebelah kiri. Di samping dua nama tersebut, ada juga yang melengkapinya dengan nama-nama sahabat nabi yaitu Abu Bakar, Umar, Utsman, dan Ali. Pola penggunaan simbol dua nama tadi, biasanya akan muncul juga dalam tampilantampilan spanduk, poster, atau sejenis gambar latar yang digunakan dalam acara-acara keislman. Tidak ditemukan satu perintah, apalagi yang mengharuskan penempatan dua nama tersebut dalam Al-Qur'an maupun hadits. Tampaknya, pemunculan nama Allah swt dan Muhammad saw, bertalian dengan keinginan untuk menempatkan penghargaan yang khusus kepada (nama) Tuhan dan nabi-Nya.

Kondisi Simbol (nama Allah dan $\mathrm{Mu}-$ hammad), pada karya kaligrafi dekorasi dimaksud, ditempatkan pada posisi yang tidak biasa. Hal yang umum, seperti telah disebutkan, dua nama tadi ditempatkan pada posisi paling tinggi di bagian tampilan benda. Nama Allah pada bagian kanan atas (pelihat) dan nama Muhammad di bagian kiri atas. Kaligrafer tampaknya tidak memperhitungkan hal itu. Dia hanya mengisi ruang kosong tertentu dengan dua simbol tadi, yaitu di bagian bawah tengah tulisan yang dominan. Kondisi ini menunjukkan bahwa kaligrafer tidak menetapkan perencanaan yang matang tentang tampilan isi karyanya.

Kata-kata yang Ditampilkan Secara Visual sebagai isi utama karya kaligrafi dekorasi, telah ditetapkan oleh panitia lomba, yaitu surat Ali-Imraan, 3: 137. Ayat 137 surat Ali Imran ini berisi perintah Allah kepada manusia muslim untuk melihat semua kejadian yang pernah menimpa ummat-ummat pada masa lalu.

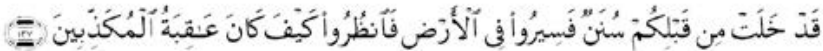

"Sesungguhnya telah berlalu sebelum kamu sunnah-sunnah Allah; karena itu berjalanlah kamu di muka bumi dan perhatikanlah bagaimana akibat orang-orang yang mendustakan (rasul-rasul)".

Gambar 3. Quran Surat Ali-Imran 137
Inti ayat tersebut bertalian dengan perintah memeriksa kembali apa yang terlah dialami oleh sejumlah masyarakat masa lalu, terutama yang tidak mengikuti aturan perintah dan larangan Allah melalui nabi-nabi-Nya. Artinya, isi ayat tersebut mengarahkan pembaca untuk bisa mengambil bahan pembelajaran tentang kejadian-kejadian buruk ummat masa lalu. Cerita kesejarahan, terutama yang menggambarkan kejadian mengerikan, seperti peristiwa Kaum Nabi Nuh, Firaun, serta Kaum 'Aad dan Tsaamud, semua terkait dengan peristiwa besar yang menjadi catatan sejarah dunia. Menimbang isi ayat tersebut, tampaknya peserta lomba tidak ada satupun yang berusaha menyesuaikan tampilan karyanya dengan tuntutan isi ayat. Mereka lebih fokus mengolah kaligrafi semata.

Pesan yang Tersurat dan Tersirat dalam Karya Kaligrafi Dekorasi yang menjadi garapan para kaligrafer peserta lomba, sama sekali tidak mempertimbangkan pesan isi ayat yang harus mereka olah. Dari delapan karya hasil lomba kaligrafi dekorasi, tak ada satupun yang berusaha mengejar pesan tersurat atau tersirat isi ayat yang dijadikan bahan karya kaligrafi. Tampaknya, para peserta hanya berkutat dengan pengaturan tulisan semata, tanpa berusaha menerapkan gambaran isi ayat sebagai bentuk pesan tersurat, apalagi tersirat. Bisa disimpulkan, untuk masalah pesan, yang tersirat maupun yang tersurat, belum tersentuh sama sekali oleh para peserta lomba karya kaligrafi dekorasi ini.

Komposisi dalam Karya Kaligrafi Dekorasi tampaknya kurang diperhitungkan oleh para kaligrafer, terutama yang terkait dengan arah pembacaan. Ada dua karya yang telah memenuhi syarat komposisi kemudahan pembacaan. Karya lainnya, sekalipun menunjukkan pola garap pembagian bidang yang templated, mengikuti apa yang pernah dibuat kaligrafer sebelumnya, tampaknya mereka banyak yang melupakan arah baca, cara susun pemotongan kalimat yang baik, juga cara memilih jenis huruf. Ada jenis huruf tertentu yang kurang nyaman pembacaannya. 


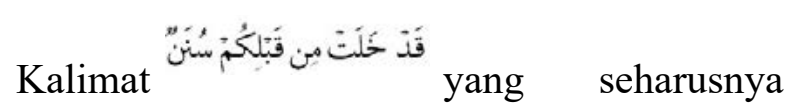
satu rangkaian, banyak yang ditulis terpisah, kemudian disatukan dengan untaian kalimat lainnya. Secara komposisi, pemotongan kata di dalam kalimat-kalimat secara keliru, menghasilkan komposisi yang menyebabkan sisi keterbacaan kurang baik. Kalimat lainnya yang kerap kurang diperhatikan adalah pemo-

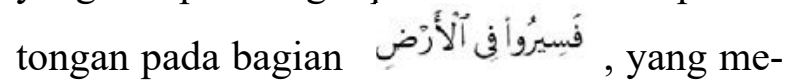
rupakan perintah lengkap: berjalanlah kamu di muka bumi. Kekeliruan pemotongan kata, penulisan kata, maupun penempatan posisi kata, dibahas dalam analisis isi kaligrafi. Dalam bidang penilaian kaligrafi, bagian kesalahan-kesalahan itu menjadi sangat vital sebagai bahan penetapan nilai karya. Kesalahan tingkat berat hingga kesalahan yang terkatagori rendah, telah diatur dalam hukum penulisan kata ayat-ayat Al-Quran yang digunakan di dalam penilaian.

Komposisi fisik yang visual juga banyak menampakkan kelemahan pengalaman peserta dalam mengelola bidang-bidang yang menjadi kajian dasar dalam karya kesenirupaan. Seperti diperkirakan dalam awal bahasan, rata-rata peserta lomba adalah mereka yang belajar kaligrafi secara otodidak, belajar dengan cara meniru kaligrafi yang telah ada, atau dibimbing oleh orang yang tidak memiliki latar kesenirupaan yang lengkap.

Keragaman Penggunaan Huruf dalam Karya Kaligrafi Dekorasi, sebagaimana aturan umum dalam lomba kaligrafi dekorasi, adalah 6 jenis huruf dasar. Huruf-huruf tersebut, sekaligus menjadi gaya penulisan, adalah $k u f i$, naskhi, riq'i, tsulutsi, farisi, dan diwani. Rata-rata karya yang dibuat para peserta lomba hanya memuat 4 jenis huruf ( 7 karya kaligrafi dekorasi) dan hanya satu karya yang menggunakan 5 jenis huruf. Huruf yang digunakan antara lain kufi, naskhi, riq'i, dan tsulutsi. Ada satu karya yang berisi tulisan gaya farisi. Tetapi lebih banyak yang menempatkan pola tulisan tertentu dengan posisi yang mempersulit pembacaan.

Jenis tulisan tsulutsi lebih banyak dipilih menjadi pola tulis kaligrafi utama. Delapan kaligrafer dekorasi menggunakan gaya tulis tsulutsi sebagai bagian pusat tampilan. Pola tulis lainnya ditempatkan di bagian atas dengan posisi miring, lurus, atau terbagi dua bagian dengan beragam jenis huruf. Pada bagian tampilan sisi kiri dan kanan, banyak digunakan untuk menempatkan pola tulis yang menuntut pembaca untuk memutar searah jarum jam. Pemilihan hurufnya cenderung kurang memperhatikan sisi keterbacaan.

Kaidah Khat pada karya kaligrafi dekorasi tampak kurang tertib. "Kebebasan" ekspresi diperkirakan menjadi penyebabutamanya. Kaligrafi dekorasi, sebagaimana kaligrafi estetis lainnya, didominasi oleh keinginan para kaligrafer dalam mengejar nilai estetis tampilan. Sekalipun tuntutan aturan di dalam lomba mengikat mereka, misalnya dengan adanya keharusan menggunakan jenis-jenis font tertentu, bahkan dalam lomba tingkat nasional, sama dengan aturan tingkat internasional, semua jenis font (gaya penulisan) harus ada dalam satu karya kaligrafi dekorasi. Atau, boleh jadi tuntutan penyelesaian jumlah gaya yang banyak juga turut menghadirkan kekurangtelitian para kaligrafer dalam memperhatikan keutuhan font, syakal, dan pemotongan kata yang salah.

Beberapa kekeliruan yang tampak dalam penulisan bagian kata dari ayat-ayat $\mathrm{Al}$ Quran dalam karya kaligrafi dekorasi, disajikan dalam kumpulan gambar berikut ini.

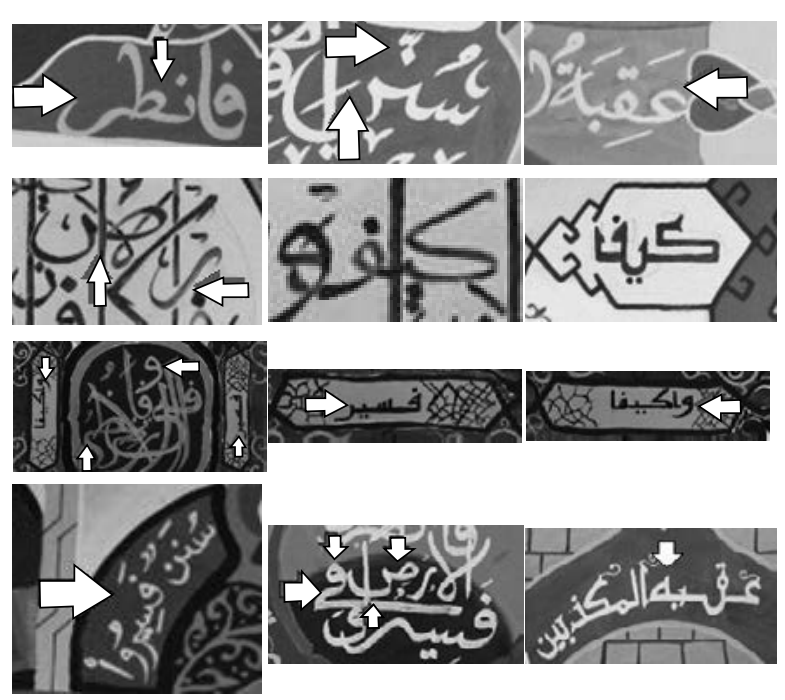




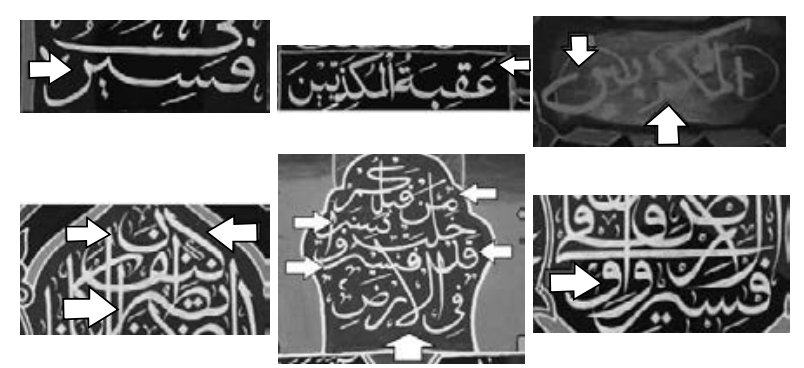

Gambar 4. Kumpulan bagian-bagian kaligrafi yang mengandung kesalahan (: salah tulis, salah tempat, salah syakal, serta kehilangan syakal dan unsur huruf)

Bentuk dan Proporsi Huruf pada enam dari delapan karya kaligrafi dekorasi yang menjadi sasaran penelitian ini menunjukkan bentuk dan proporsi huruf yang kurang mantap. Beberapa di antaranya mengindikasikan kondisi kaligrafer yang kurang memahami dasar-dasar penulisan kaligrafi Arab. Dalam banyak kegiatan MTQ Khattil Quran, kondisi ini menjadi ciri utama para peserta lomba. Banyak peserta lomba yang mengutamakan kemampuan mengolah tampilan ornamen kaligrafi dibanding kemampuan menulis kaligrafi yang baik.

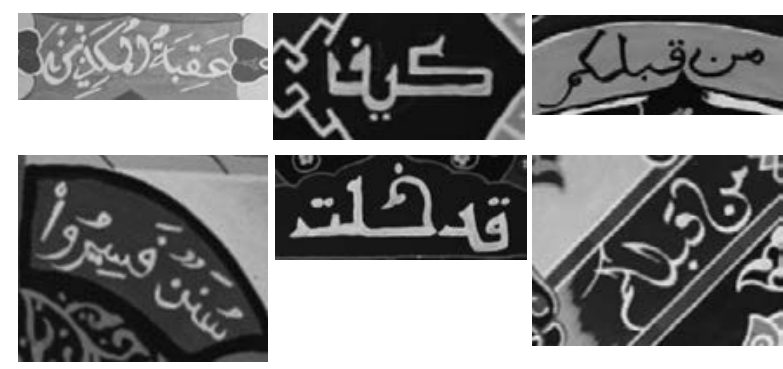

Gambar 5. Contoh kumpulan bentuk dan proporsi huruf yang masih belum menampakkan kondisi penguasaan dasar penulisan huruf Arab yang benar. Boleh jadi, karena tuntutan yang harus dipenuhi dalam menulis kaligrafi dekorasi ini adalah kemampuan menulis semua pola jenis huruf. Beberapa peserta baru bisa menguasai beberapa pola tulis saja, sementara tata tulis jenis huruf tertentu masih belum dikuasai secara maksimal. Hal ini berbeda dengan peserta lomba khat naskah dan mushaf yang (umumnya) hanya dituntut menguasai satu pola tulis jenis huruf naskhi saja.
Jarak spasi dan letak huruf masih menjadi persoalan utama pada semua karya kaligrafi hasil lomba khat dekorasi pada $M T Q$ Ke-26 Tingkat Kabupaten Buleleng. Para peserta lomba masih belum memperhatikan jarak spasi dan letak huruf yang benar. Banyak peserta lomba yang terlalu asyik dengan keindahan yang mereka susun, sementara itu banyak bagian tulisan yang terlupakan perancangannya secara benar. Tata aturan pola tulis huruf-huruf dalam kaligrafi bahasa Arab, juga bahasa lainnya, akan sangat terkait dengan fungsi utama kaligrafi, yaitu sebagai benda komunikasi, bukan sekadar karya estetis.

Keserasian dan Komposisi Antar huruf rata-rata masih kurang tertata. Hal itu menyebabkan keserasian penempatannya secara visual kurang tampak. Persoalan lain yang secara visual bisa mengganggu tampilan adalah masalah pemilihan warna. Kebanyakan peserta lomba khat dekorasi ini melupakan rancangnan awal karya yang matang. Mereka bekerja berdasarkan naluri estetis semata. Karya diolah sejalan dengan selera dan keinginan yang kurang terbimbing oleh tertibrancangan. Padahal, ada sesuatu yang harus diutamakan dalam penataan karya kaligrafi, misalnya keserasian penempatan jenis huruf yang sekaligus menyangkut masalah komposisi karya secara keseluruhan.

Ada pola tulis yang disusun dari bawah ke atas atau sebaliknya. Hal itu masih mudah ditelusuri arah bacanya. Tetapi, ada juga yang menempatkan huruf secara tidak tertib, hanya mengisi bagian kosong ruang gambar, sehingga isi tulisan menjadi kabur. Begitu juga tampak dalam pengulangan kata yang menyalahi isi bacaan. Kondisi tadi tampaknya muncul sejalan dengan pola kerja yang lepas dari tertibrancangan.

\section{Keterbacaan Tulisan}

Huruf-huruf dalam kaligrafi itu harus dibaca oleh penikmat karya. Ada beberapa bagian karya yang seharusnya dipermudah pembacaan isinya dengan cara menempatkan jenis pola penulisan huruf tertentu. Secara visual, ada sejumlah huruf yang secara fisik memerlu- 
kan cara baca yang telaten, sekalipun letaknya normal. Pola tulis jenis huruf ini kadang dipersulit pembacaannya dengan menempatkannya pada posisi miring atau bahkan vertikal. Pola tulis tsuluts, pola tulis huruf yang cenderung bertumuk dan berjalin, kerap disusun dengan pola baca yang tertib. Tetapi, ketika kaligrafer hanya mengejar pengisian ruang gambar, banyak pola baca yang mulai tidak tertib arahnya. Lebih khusus dalam menempatkan jenis-jenis huruf tertentu yang seharusnya diperhitungkan kemudahan bacanya. Di samping hal tadi, masalah keindahan huruf tertentu akan sangat terasa ketika posisi penulisannya sesuai dengan karakter huruf tersebut.

\section{Kesalahan Penulisan}

Kesalahan penulisan, seperti telah diuraikan dalam bagaian bahasan kaidah khat, lebih banyak terkait dengan ketidaktertiban cara tulis. Kehilangan titik, salah syakal, dan kehilangan huruf tertentu, dalam hukum pembacaan menjadi sangat berat kekeliruannya. Hal itu umum terjadi karena kaligrafer kurang teliti dalam memperhatikan karakter huruf maupun tata cara penulisannya. Pada beberapa kondisi, ada bagian huruf yang tidak lengkap. Misalnya huruf kaf yang bisa ditulis tanpa penutup atas tetapi harus dilengkapi huruf hamzah kecil, dua penanda tadi hilang: tidak ada hamzah atau tidak menggunakan penutup atas. Hal lain yang kerap muncul sebagai kesalahan umum adalah huruf yang ditulis kehilangan geriginya, misalnya huruf sin ketika bersambung dengan huruf lain geriginya harus tiga, sementara ketika lepas sebagai huruf akhir geriginya hanya dua, menjadi kehurangan gerigi pada penulisannya. $\mathrm{Hu}-$ ruf $d z a l$ atau $d a l$ yang ditulis melebihi batas garis dasar maya sehingga bentuknya seperti zay atau ra. Kesalahan-kesalahan tadi menjadi sangat berat karena terkait dengan perubahan makna kata.

Kesalahan penulisan lainnya terkait dengan penggayaan huruf yang berlebihan. Kondisi ini tampak pada penulisan huruf yang cenderung digayakan tanpa pedoman yang benar. Kaidah penulisan huruf, dalam kaitan dengan masalah ini, seakan terlupaan karena dominasi keinginan menghias.

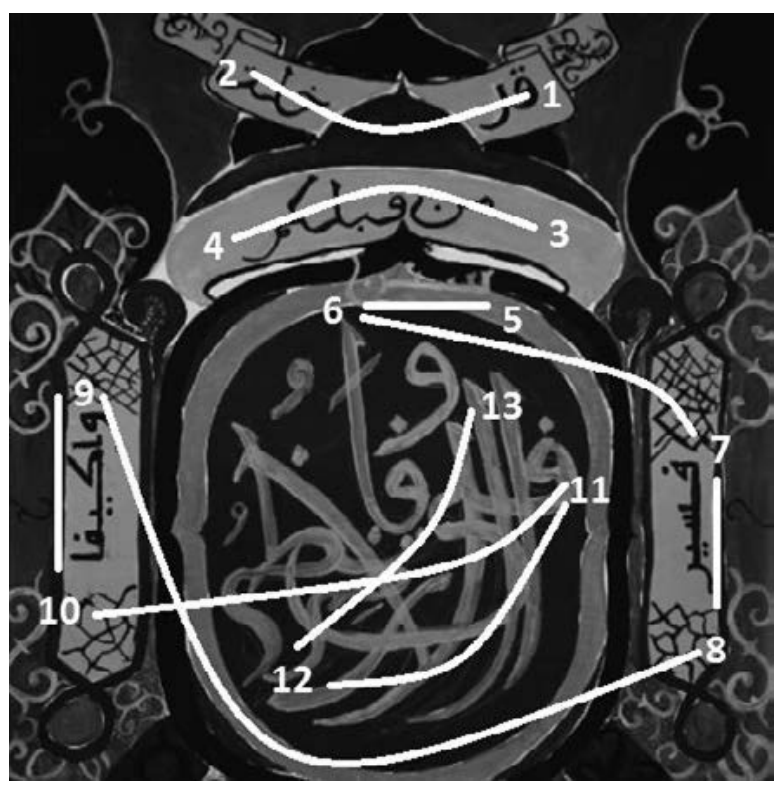

Gambar 6. Salah satu contoh pola baca yang kurang terancang secara baik.

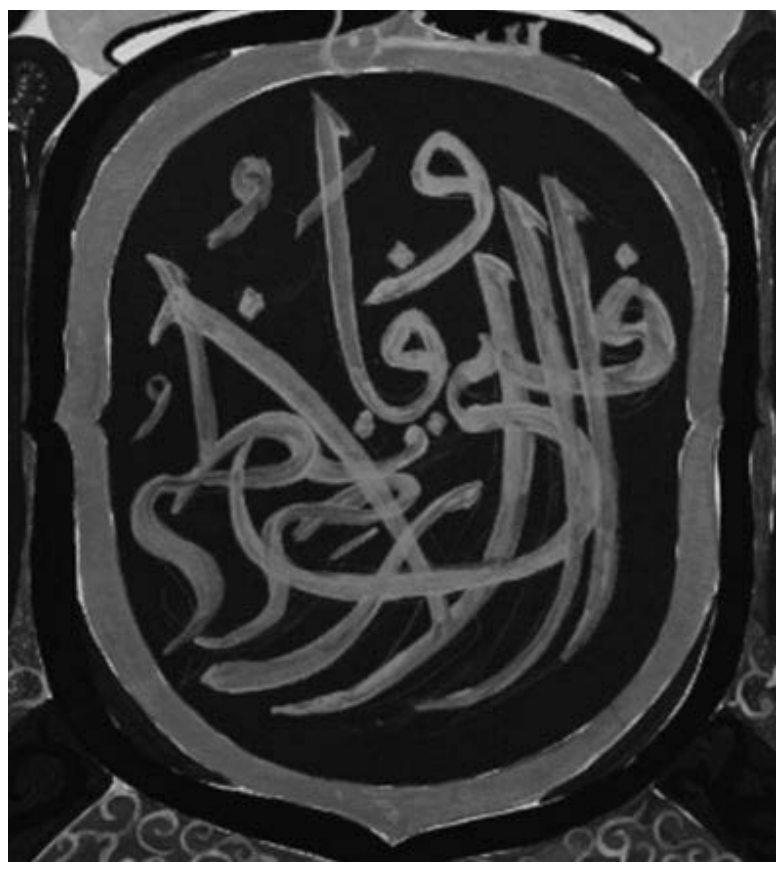

Gambar 7. Salah satu contoh karya kaligrafi yang penggarapan hurufnya berlebihan.

\section{PENUTUP}

Jika dibandingkan dengan warnawarna pada karya kaligrafi dekorasi, warna kaligrafi mushaf yang mengunakan bahan dasar kertas karton tampak lebih cerah. Tampaknya, kendala bahan tidak begitu dirasakan oleh para peserta lomba kaligrafi mushaf. Hal 
itu tampak pula dalam masalah objek garis. Garis-garis yang dihasilkan pada karya kaligrafi mushaf sangat tegas. Lebih khusus untuk bagian tulisan. Perangkat kerja yang digunakan dalam membuat kaligrafi mushaf adalah perangkat tulis kaligrafi yang umum. Sifat alat tulis berupa pena asli (berbahan metal) maupun pena buatan (berbahan bambu, lidi aren, atau kayu), sangat kentara tertib jejaknya.

Font yang diolah hanya satu jenis huruf, yaitu huruf naskhi, huruf standar untuk penulisan naskah mushaf. Hal ini cukup meringankan bagi kaligrafer yang taat aturan penulisan. Biasanya, masalah kmposisi tulisan pun sangat bergantung kepada pola komposisi naskah normal, rata tengah. Halaman pembuka tunggal yang umum menjadi acuan dalam pengolahan tampilan halaman. Oleh karena itu, pola keseimbangan tampilan hanya halaman tunggal. Kecenderungan penyusunan tulisan antara rata tengah dengan rata kiri-kanan adalah pilihan yang "pasti". Beban pada pengolahan hiasan pun tidak terlalu berat dari sisi pengaturan komposisi. Komposisi sentral bisa menjadi pilihan utama.

Keseimbangan hiasan yang biasa digunakan dalam tampilan halaman awal (tengah; dua halaman) mushaf sudah pasti mengikuti pola rata tengah. Di sini, masalah komposisi hiasan adalah hal yang diikat oleh pakem atau konvensi awal. Isi hiasan adalah kebebasan yang teruji di semua negara. Artinya, dari negara manapun kaligrafer itu berasal, biasanya selalu menyertakan hiasan khas milik negaranya yang dianggap cocok. Keragaman itu menjadi sangat menarik. Peserta lomba $M T Q$ Khattil Quran ke-26 Kabupaten Buleleng, juga menampakkan hal tersebut. Banyak unsur hiasan khas masyarakat Bali yang dianggap umum masuk dalam hiasan mushaf karya mereka.

\section{DAFTAR PUSTAKA}

Akbar, Ahmed and Lawrence Rosa. 2001. Discoveries Islam Making Sense Of Muslim History and Society. New York: Routledge Akbar, Ali. 1995. Kaidah Menulis dan Karya-kar- ya Master Kaligrafi Islam. Jakarta: Pustaka Firdaus

Akbar, Ali. 2008. Membalik Sejarah Pengumpul an dan Penulisan Alquran. Makalah. Riau: Universitas Islam Negeri Sultan SyarifKasim

Akbar, Ali. 2012. Dalam http://mushafnusantara. blogspot.com

Alam, Masrul. 2015. Dalam http://tilawah-lpu. blogspot.co.id/2015/06/cabang-lombadalam-mtq.html

http://ahmadfauzanalamsyah.blogspot.co.id/2014/ 01/hasil-karya-para-khatat-di-mtq-nasio nal.html

http://id.wikipedia.org.http://kaligrafi-manbaureno.blogspot.co.id/2012/02/karyafinalis-mtq-nasional-bengkulu. html\#links

http://mushafnusantara. blogspot.com

http://septiyenabdullah.blogspot.com/2013/, diakses Rabu, 23 Maret 2016, 10:35

http://tilawah-lpu.blogspot.co.id/2015/06/cabanglomba-dalam-mtq.html

Kadir, Ismail. 2014. Dalam http://hiasanmushaf. blogspot.co.id/2014/06/kaligrafi-naskahmtq-nasional-xxv-batam.html

Panduan Musabaqah Tilawatil Quran (MTQ) Mahasiswa Tingkat Regional Jawa Timur IV Tahun 2016

Quran Player Versi 2.1.0.0, Copyright $\subseteq 2005-2007$ Wawan Sjachriyanto, www.sahryainfor ma.com

Serianz. 2005. The NARA Photo Analysis Sheet. 